\title{
PENGARUH MODEL PEMBELAJARAN INKUIRI TERBIMBING DAN KREATIVITAS TERHADAP KETERAMPILAN PROSES SAINS PADA SISWA SMA
}

\author{
Nuraini Fatmi dan Sahyar \\ Program Studi Pendidikan Fisika Unimed
}

\begin{abstract}
Abstrak. Penelitian ini bertujuan untuk mengetahui: 1) Perbedaan keterampilan proses sains siswa yang dibelajarkan dengan model inkuiri terbimbing dengan siswa yang dibelajarkan dengan pembelajaran konvensional, 2) Perbedaan keterampilan proses sains pada siswa yang memiliki tingkat kreativitas tinggi dan pada siswa yang memiliki tingkat kreativitas rendah, 3) Interaksi antara kreativitas dengan model pembelajaran inkuiri terbimbing terhadap keterampilan proses sains siswa. Penelitian ini merupakan penelitian quasi eksperimen dengan desain faktorial $2 \times 2$. Populasi penelitian adalah seluruh siswa kelas $\mathrm{X}$ pada SMAN I Julok semester genap tahun pelajaran 2013/2014. Sampel penelitian terdiri dari dua kelas yang ditentukan dengan cluster sampling diambil dari dua kelas, yaitu siswa kelas X-2 (eksperimen) sebanyak 30 orang dan siswa X-5 (kontrol) sebanyak 30 orang. Instrumen penelitian berupa tes kreativitas dan tes keterampilan proses sains. Hipotesis dianalisis dengan bantuan SPSS 17 for windows pada taraf signifikan 0,05. Berdasarkan analisis data dan uji hipotesis yang dilakukan diperoleh bahwa: 1) Terdapat perbedaan keterampilan proses sains antara siswa yang menggunakan model pembelajaran Inkuiri terbimbing dibandingkan dengan siswa yang menggunakan pembelajaran konvensional. 2) Terdapat perbedaan keterampilan proses sains siswa yang memiliki tingkat kreativitas tinggi dengan siswa yang memiliki tingkat kreativitas rendah, dimana siswa memiliki tingkat kreativitas tinggi memperoleh keterampilan proses lebih tinggi dibandingkan dengan siswa yang memiliki tingkat kreativitas rendah. 3) Ada interaksi antara kreativitas dengan model pembelajaran inkuiri terbimbing terhadap keterampilan proses sains siswa.
\end{abstract}

Kata kunci: model pembelajaran, inkuiri terbimbing, kreativitas, keterampilan proses sains

\section{THE EFFECT OF GUIDANCE INQUIRY LEARNING MODELS AND CREATIVITY TO SCIENCE PROCESS SKILL ON SENIOR HIGH SCHOOL STUDENTS}

\author{
Nuraini Fatmi and Sahyar \\ Physics Education Program-State University of Medan
}

\begin{abstract}
This research aimed to find out: 1) The difference of students achievement of science proses skills between guided inquiry learning model and convensional learning, 2) the difference of students achievement of science proses skills for students of high learning creativity with those who had low learning creativity, 3) The interaction of creativity with guided inquiry learning model related to science proses skills. This research used a quasi experiment
\end{abstract}


method with $2 \times 2$ factorial design. The population of this research is students of second semester of grade X SMAN I Julok of academic year 2013/2014. The samples of this research were two classes, which was determined using cluster random sampling. The first sample is X-2 (experiment) consist of 30 student and the second sample is X-5 (control) consist of 30 student. The hypotheses were analyzed using SPSS 17.0 for windows with 0,05 level of significance. The results of data analysis in this research, shows that: 1) There are differences of physics students achievement of science proses skills using guided inquiry learning model compared to convensional learning, 2) There are differences of physics students achievement of science proses skills between students of high learning creativity with those who had low learning creativity, 3) Interaction is exist between learning creativity with guided inquiry learning model on science proses skills.

Keyword: guided inquiry, learning model, creativity, science proses skills

\section{PENDAHULUAN}

Perbaikan mutu pendidikan dapat dilakukan dengan perbaikan sistem belajar dan pembelajaranya. Dalam buku psikologi pendidikan menjelaskan bahwa inti kegiatan pendidikan adalah proses belajar dan pembelajaran. Belajar dapat berlangsung secara internal terhadap semua pengalaman belajar dan dapat berlangsung melalui pengalaman yang dirancang guru (Sanjaya, 2008).

Kualitas pendidikan saat ini belum menunjukkan relevansi yang tinggi dengan kebutuhan masyarakat. Ilmu fisika yang diterapkan di sekolah seakan-akan tidak berdampak dalam cara hidup dan cara berpikir siswa di lingkungannya. Hal ini dibuktikan oleh hasil observasi awal peneliti dengan guru bidang studi fisika di sekolah SMAN 1 Julok, yang menunjukkan bahwa selama ini pembelajaran fisika masih berorientasi pada telling science, belum bergeser ke orientasi doing science, hal ini mengakibatkan pembelajaran hanya berfokus pada kegiatan menghafal konsep, sehingga siswa kesulitan dalam memahami konsep fisika.

Berdasarkan hasil observasi lanjutan yang telah dilakukan di SMA Negeri 1 Julok pada tanggal 19 September 2013, diperoleh informasi, bahwa pembelajaran fisika yang berlangsung masih didominasi oleh guru serta kurang bervariasi. Proses pembelajaran lebih sering menggunakan metode ceramah. Pembelajaran yang berlangsung masih konvensional dengan latihan soal, sehingga kurangnya kesempatan siswa untuk memiliki pengalaman belajar yang nyata dan aktif. Kegiatan praktikum juga jarang dilaksanakan sehingga mengakibatkan keterampilan proses siswa menjadi pasif dan kurang terbentuk, dimana siswa hanya mengikuti apa yang dicontohkan guru dan kreativitas yang ada dalam diri siswa jadi pun terhambat serta mengalami penurunan hasil belajar siswa. Hal ini berdampak pada hasil ulangan siswa di semester ganjil 2011/2012 memperoleh angka kurang memuaskan, yaitu dengan nilai rata-rata 60 sedangkan KKM bernilai 70 .

Salah satu model pembelajaran yang dapat digunakan untuk memperoleh hasil belajar yang baik pada karakteristik kompetensi keterampilan siswa adalah model pembelajaran inkuiri dengan jenis bimbingan. Terdapat beberapa jenis inkuiri yang dapat digunakan sesuai dengan keadaan siswa yang bersangkutan, diantaranya adalah Discovery Learning, Interactive Demonstration, Guided Inquiry, Inquiry Laboratorium, Hypothetical Inquiry (Wenning, 2010). Berdasarkan keadaan siswa yang diamati di sekolah SMAN 1 Julok, maka jenis inkuiri yang cocok digunakan dalam penelitian ini adalah inkuiri terbimbing, karena pada proses pelaksanaannya guru memberikan 
bimbingan atau petunjuk yang cukup luas kepada siswa dalam merencanakan pembelajaran dan perumusan kegiatan.

Model pembelajaran inkuiri terbimbing adalah suatu model pembelajaran yang melatih siswa dalam menemukan permasalahan dan melakukan penyelidikan sampai akhirnya memperoleh kesimpulan tentang hasil permasalahan (Wenning, 2010). Pada penelitian ini langkah-langkah pembelajaran dengan model inkuiri terbimbing mengacu pada National Science Education Standard (NRC, 2000) yang menyatakan bahwa dalam tahapan dan prosedur pembelajaran yang didasari oleh inkuiri. Untuk K-4 ada enam aspek yang harus dimunculkan yaitu merumuskan masalah, merencanakan penelitian dan melaksanakan penelitian, pengumpulan data, membuat penjelasan berdasarkan data hasil observasi serta mengkomunikasikan hasil penelitian. Tahapan dan prosedur pada grade K-4 dianggap sesuai dengan inkuiri jenis terbimbing karena langkahnya tidak terlalu banyak dan mudah dalam memberikan bimbingan kepada siswa. Dengan demikian model pembelajaran inkuiri terbimbing perlu mengacu ke penelitian yang relevan.

Menurut Sabahiyah (2013) menyatakan bahwa model pembelajaran inkuiri terbimbing yang diterapkan dalam penelitian ini terbukti berpengaruh terhadap pemahaman konsep IPA dan keterampilan proses sains. Selanjutnya Menurut Gladys (2013) menyatakan bahwa pendekatan inkuiri terbimbing efektif digunakan untuk mengatasi kesulitan belajar siswa. Pemaparan tersebut sejalan dengan definisi dari model pembelajaran inkuiri terbimbing, sebagaimana yang dikemukakan oleh Sun dan Trowbridge (1973) yang menyatakan bahwa model pembelajaran inkuiri terbimbing merupakan suatu proses menemukan dan menyelidiki masalah-masalah, menyusun hipotesis, merencanakan eksperimen, mengumpulkan data, menarik kesimpulan data dan menarik kesimpulan tentang hasil masalah.

Berdasarkan definisi inkuiri terbimbing di atas, maka untuk memudahkan dalam mewujudkan suatu proses penyelidikan yang berorien- tasi inkuiri diperlukan tingkat kreativitas yang ada pada diri siswa. Karena dengan adanya kreativitas maka siswa akan lebih terampil dalam melakukan kegiatan praktikum. Hal ini diperlukan untuk menunjang proses pembelajaran. Maka dalam penelitian ini alat praktikum sederhana yang digunakan adalah alat optik sederhana yang dirancang oleh siswa sendiri melalui petunjuk guru yang disajikan dalam bentuk lembar kerja siswa.

Hal ini dilakukan supaya siswa lebih terampil sehingga kreativitas yang ada pada diri siswa dapat terlatih dan keterampilan proses sains pun dapat terbentuk. Semiawan (2009) mengemukakan bahwa bahwa kreativitas merupakan kemampuan untuk memberikan gagasan-gagasan baru dan menerapkannya dalam pemecahan masalah.

Hal ini sesuai dengan kurikulum 2013 yang menyatakan untuk mengetahui hasil belajar siswa harus berorientasi pada karakteristik kompetensi yaitu: ranah sikap, ranah keterampilan dan ranah pengetahuan. Jadi jenis keterampilan dalam penelitian ini adalah keterampilan proses sains, menurut Semiawan (2009) keterampilan proses sains adalah keterampilan fisik dan mental terkait dengan kemampuan-kemampuan yang mendasar yang dimiliki, dikuasai, dan diaplikasikan dalam suatu kegiatan ilmiah, sehingga para ilmuan berhasil menemukan sesuatu yang baru. Pada penelitian ini indikator dari keterampilan proses sains mengacu pada Sani (2012), yang menyatakan bahwa aspek keterampilan proses sains meliputi: Melakukan pengamatan (observasi), inferensi, mengajukan pertanyaan, menafsirkan hasil pengamatan (interpretasi), Mengelompokkan (klasifikasi), Meramalkan (prediksi), Berkomunikasi, Membuat hipotesis, Merencanakan percobaan (penyelidikan), Menerapkan konsep atau prinsip, Keterampilan menyimpulkan.

Menurut Haryono (2006) rendahnya kemampuan proses sains siswa setidaknya dapat dijelaskan dari aspek proses pembelajaran yang berlangsung dan dari aspek sistem penilaian yang dikembangkan oleh para guru. Sedangkan menurut Suwartaya (2013) menyatakan bahwa 
sistem evaluasi yang dikembangkan oleh para guru selama ini kurang mendorong bagi perkembangan keterampilan proses sains siswa, evaluasi kemampuan proses sains dilakukan secara terintegrasi dengan evaluasi hasil belajar pada umumnya dalam bentuk tes tertulis.

Permasalahan yang dikaji dalam penelitian ini meliputi: (1) Apakah terdapat perbedaan keterampilan proses sains siswa yang dibelajarkan dengan model inkuiri terbimbing dengan siswa yang dibelajarkan dengan pembelajaran konvensional. (2) Apakah terdapat perbedaan keterampilan proses sains pada siswa yang memiliki tingkat kreativitas tinggi dan pada siswa yang memiliki tingkat kreativitas rendah. (3) Apakah terdapat interaksi antara kreativitas dengan model pembelajaran inkuiri terbimbing terhadap keterampilan proses sains siswa.

\section{METODE PENELITIAN}

Populasi dalam penelitian ini adalah seluruh siswa kelas X pada SMA Negeri I Julok semester genap tahun pelajaran 2013/2014. Sampel penelitian ini sebagian anggota populasi, sampel yang diambil dengan menggunakan teknik cluster sampling, dengan cara mengambil sampel secara acak sehingga diperoleh sampel kelas eksperimen pada kelas $\mathrm{X}^{2}$ dan kelas kontrol pada kelas $X^{5}$ di SMAN I Julok pada semester genap tahun pelajaran 2013/2014 yang mempunyai kemampuan yang berbeda-beda.

Penelitian ini merupakan jenis penelitian quasi-eksperimen (quasi experiment) pretespostes dengan rancangan Desain Faktorial 2x2. Oleh karena itu pelaksanaannya menggunakan siswa kelas eksperimen yang diterapkan model pembelajaran inkuiri terbimbing, pada kelas kontrol dengan pembelajaran konvensional. Pengujian hipotesis penelitian dengan menggunakan teknik analisi varians (anova) dua jalur pada taraf signifikan $\alpha=5 \%$. Data dianalisis menggunakan Software SPSS 17.

\section{HASIL PENELITIAN DAN PEMBAHASAN}

Adapun untuk analisis data tes awal (pretes), setelah data terdistribusi normal dan homogen terdapat dalam ringkasan data pretes kelompok sampel pada Tabel 1.

Tabel 1. Ringkasan Data Pretes Kelompok Sampel

\begin{tabular}{cccccc}
\hline \multirow{2}{*}{ Kelas } & \multicolumn{5}{c}{ Tes Awal Keterampilan Proses Sains } \\
\cline { 2 - 6 } & $\mathrm{N}$ & $\begin{array}{r}\text { Nilai } \\
\text { Maks. }\end{array}$ & $\begin{array}{l}\text { Nilai } \\
\text { Min. }\end{array}$ & $\begin{array}{c}\text { Re- } \\
\text { rata }\end{array}$ & $\begin{array}{c}\text { Simpa } \\
\text { Ngan } \\
\text { Baku }\end{array}$ \\
\hline Eksperimen & 30 & 48,00 & 18,00 & 31,67 & 8,19 \\
\hline Kontrol & 30 & 43,00 & 18,00 & 30,33 & 7,16 \\
\hline
\end{tabular}

Berdasarkan data pada Tabel 1 dapat dilihat bahwa rata-rata nilai pretes pada kelas eksperimen dan kelas kontrol masing-masing adalah 31,67 dan 30,33. Sementara itu, simpangan baku untuk kelas eksperimen adalah 8,19 sedangkan simpangan baku untuk kelas kontrol adalah 7,16. Berdasarkan data tersebut terlihat bahwa rata-rata nilai pretes kelas eksperimen sedikit lebih besar dibandingkan kelas kontrol. Namun untuk mengetahui secara lebih jelas mengenai kemampuan awal siswa kelas eksperimen sama atau tidak dengan kelas kontrol, maka dilaksanakan uji kesamaan dua rata-rata dengan taraf signifikansi 5\%.

Berdasarkan hasil analisis data dapat dilihat bahwa nilai Sig. (2-tailed) pada uji hipotesis dua pihak adalah 0,59 . Karena nilai signifikansinya lebih besar dari 0,05 maka $\mathrm{H}_{0}$ diterima atau hasil keterampilan proses sains siswa pada tes awal (pretes) kedua kelas tersebut tidak berbeda secara signifikan. Sehingga dengan tidak adanya perbedaan kemampuan awal siswa antara kelas ekperimen dan kelas kontrol maka dapat dilakukan uji hipotesis yaitu dengan menggunakan anova dengan bantuan pogram SPSS 17.0.

Penelitian ini juga bertujuan untuk melihat kreativitas para siswa. Skor kreativitas masingmasing kelompok sampel akan dikategorikan menjadi kreativitas tinggi dan kreativitas rendah yang dilihat berdasarkan rata-rata skor kreativitas. Berdasarkan pengelompokkan tingkat kreativitas pada kelas eksperimen dan kelas kontrol maka diperoleh nilai rata-rata skor kreativitas untuk kelas eksperimen sebesar 62,33 dan kelas kontrol 55,00. Hasil pengelompokan 
diperoleh jumlah siswa untuk kategori kreativitas tinggi sebanyak 15 orang untuk kelas eksperimen dan 17 orang untuk kelas kontrol sedangkan kelompok kreativitas rendah berjumlah 15 orang untuk kelas ekperimen dan 13 orang untuk kelas kontrol.

Persentase tingkat kreativitas setiap indikator lebih tinggi dimiliki oleh kelas eksperimen. Indikator yang memiliki persentase paling tinggi adalah rasa ingin tahu sebesar $82,22 \%$ di kelas eksperimen dan $71,11 \%$ di kelas kontrol, sedangkan yang paling rendah adalah sifat menghargai yaitu $46,33 \%$ di kelas eksperimen dan $37,00 \%$ di kelas kontrol. Hal ini dapat disimpulkan bahwa siswa di kedua kelompok sampel dominan memiliki rasa ingin tahu dari pada indikator yang lain dan yang paling sedikit dimiliki oleh siswa adalah sifat menghargai.

Berdasarkan hasil analisis data diperoleh bahwa rata-rata nilai postes pada kelas eksperimen dan kelas kontrol masing-masing adalah 77,50 dan 69,17. Sementara itu, simpangan baku untuk kelas eksperimen adalah 11,55 sedangkan simpangan baku untuk kelas kontrol adalah 9,16. Berdasarkan data tersebut terlihat bahwa rata-rata nilai postes kelas eksperimen lebih besar dibandingkan dengan rata-rata nilai postes kelas kontrol.

Berdasarkan hasil perhitungan didapat rata-rata gain hasil keterampilan proses sains pada siswa kelas eksperimen sebesar 0,68 dan kelas kontrol sebesar 0,55. Nilai rata-rata gain jika berdasarkan kategori interpretasi indeks gain yang dikemukakan oleh Hake, maka kategori indeks gain hasil keterampilan proses sains kelas eksperimen dan kontrol keduaduanya sedang.

Pada kelas eksperimen indikator melakukan pengamatan memperoleh gain sebesar 0,93 dengan kategori tinggi, pada kelas kontrol sebesar 0,74 dengan kategori tinggi. Hal ini membuktikan bahwa pada model pembelajaran inkuiri terbimbing menekankan pada proses mengamati secara langsung. Sedangkan perolehan gain terendah pada Indikator berkomunikasi, kelas eksperimen memperoleh gain sebesar 0,28 kategori rendah, kelas kontrol sebesar 0,20 kategori rendah. Pada kedua kelas ini masih menunjukkan peningkatan yang rendah pada indikator berkomunikasi. Hal ini dapat disebabkan kurangnya kerjasama yang terbentuk dalam kelompok yang dibuat.

Adapun hasil perhitungan anova faktorial $2 \times 2$ menggunakan bantuan SPSS 17.0. Hasil output yang digunakan untuk menguji hipotesis dalam penelitian ini dapat dilihat pada Tabel 2 .

Tabel 2. Hasil Uji Anova

\begin{tabular}{lcrcc}
\hline \multicolumn{1}{c}{ Jumlah Variasi } & Df & $\begin{array}{c}\text { Kata-Rata } \\
\text { Kuadrat }\end{array}$ & \multicolumn{1}{c}{ F } & Sig. \\
\hline Model_Pembelajaran & 1 & 1232,11 & 28,56 & 0,00 \\
\hline Tingkat Kreativitas & 1 & 3624,10 & 83,99 & 0,00 \\
\hline Tingkat Kreativitas & 1 & 244,17 & 5,66 & 0,02 \\
$\begin{array}{l}\text { Dengan Model } \\
\text { Pembelajaran }\end{array}$ & & & & \\
\hline Total & 60 & & & \\
\hline
\end{tabular}

\section{Hipotesis pertama}

Diperoleh nilai Sig. sebesar 0,00. Oleh karena, nilai Sig. $0,00<0,05$, maka dapat dikatakan bahwa hasil pengujian menolak Ho atau menerima Ha dalam taraf alpha 5\%. Hasil keterampilan proses sains siswa yang diberi model pembelajaran Inkuiri terbimbing lebih baik dari pada pembelajaran konvensional.

\section{Hipotesis Kedua}

Hasil uji anova pada kolom tingkat kreativitas diperoleh nilai sig. sebesar 0,00. Oleh karena, nilai Sig. $0,00<0,05$, maka dapat dikatakan bahwa hasil pengujian menolak Ho atau menerima Ha dalam taraf alpha 5\%. Hasil postes keterampilan proses sains siswa yang memiliki tingkat kreativitas tinggi lebih baik daripada postes keterampilan proses sains yang memiliki tingkat kreativitas rendah.

\section{Hipotesis Ketiga}

Berdasarkan hasil uji anova pada kolom tingkat kreativitas dengan model pembelajaran diperoleh nilai sig. sebesar 0,02. Oleh karena, nilai Sig. 0,02<0,05, maka dapat dikatakan bahwa hasil pengujian menolak Ho dan atau menerima $\mathrm{Ha}$ dalam taraf alpha 5\%. Hasil pengujian hipotesis penelitian di atas dapat menggambarkan interaksi antara tingkat kreati- 
vitas dengan model pembelajaran terhadap keterampilan proses sains siswa.

\section{SIMPULAN}

Hasil penelitian ini dapat disimpulkan sebagai berikut:

1. Berdasarkan dari hasil keterampilan proses sains yang telah dicapai oleh kelas ekperimen dan kelas kontrol, yaitu terdapat perbedaan hasil keterampilan proses sains antara kelas ekperimen dan kelas kontrol. Kelas ekperimen mengalami peningkatan gain ternormalisasi rata-rata sebesar 0,68 dengan kategori sedang dan kelas kontrol mengalami peningkatan gain ternormalisasi rata-rata sebesar 0,55 dengan kategori sedang.

2. Hasil keterampilan proses sains siswa yang memiliki tingkat kreativitas tinggi lebih baik dibandingkan dengan keterampilan proses sains siswa yang memiliki tingkat kreativitas rendah. Hal ini juga di tandai dari perolehan indikator yang dominan muncul pada kelas eksperimen adalah indikator rasa ingin tahu sebesar $82,22 \%$ di kelas eksperimen dan $71,11 \%$ di kelas kontrol.

3. Terdapat interaksi model pembelajaran inkuiri terbimbing dan konvensional dengan tingkat kreativitas terhadap keterampilan proses sains siswa. Siswa yang memiliki tingkat kreativitas tinggi yang dibelajarkan dengan inkuiri terbimbing memperoleh hasil keterampilan proses sainsnya lebih tinggi dibandingkan dengan siswa yang memiliki tingkat kreativitas tinggi yang dibelajarkan dengan pembelajaran konvensional.

\section{DAFTAR PUSTAKA}

Haryono. 2006. Model Pembelajaran Berbasis Keterampilan Proses Sains. Jurnal Pendidikan Dasar. Vol. 7 (1). Hal: 8-9 (online). (http://journal.unnes.ac.id/sju/index.php/j pe, diakses 20 Nov. 2013).

Jack, Gladys.U. 2013. Consept Mapping and Guided Inquiry as Effective Techniques for Teaching Difficult Concepts in Chemistry: Affect on Students Academic Arhievement. Journal of education and practice. Vol. 6 (2), hal: 11-12, (online). (http://www.tused.org, diakses 20 Nov. 2013).

NRC. 2000. Inquiry and The National Science Education Standar. A Guide For Teaching and Learning. Washington DC: National Academic Press.

Sani, R.A. 2012. Pengembangan Laboratorium Fisika. Medan: Unimed Press.

Sanjaya, W. 2008. Strategi Pembelajaran Berorientasi Standar Proses Pendidikan. Jakarta: Prenada Media Group.

Sabahiyah, A.A.I.N, Mathaeni, I. W dan Suastra. 2013. Pengaruh Model Pembelajaran Inkuiri Terbimbing Terhadap Keterampilan Proses Sains dan Penguasaan Konsep IPA Siswa Kelas V Gugus 03 Wanasaba Lombok Timur. Jurnal Pendidikan Dasar. Volume: 3 (3), hal: 4-5. (online). (http:// journal.ganesha.ac.id, diakses 21 Nov. 2013).

Semiawan. 2009. Pendekatan Keterampilan Proses. Jakarta: Grasindo.

2009. Memupuk Bakat dan Kreativitas Siswa Sekolah Menengah. Jakarta: Gramedia.

Suwartaya, Nugroho, S.E dan Khumaedi. 2013. Pengembangan Perangkat Pembelajaran Model Inkuiri Terbimbing Berefleksi Pada Materi Konduktor dan Isolator Panas. Journal of Primary Education. Vol 2 (1). Hal 3-4. (online). (http:// journal.unnes.ac.id/sju/index.php/jpe, diakses 20 Nov. 2013).

Sund, R dan Trowbrige, L. 1973. Teaching Sciences by Inquiry in The Secondary School. Ohio: Bell and Howell Company. Wenning, C.J. 2010. Level of Inquiry: using inquiry spectrum learning sequences to teach science. JPTEO. Vol. 5 (3), hal: 7-8. (online). (http://journal JPTEO, diakses 20 Nov. 2013). 